\title{
God Andjety in ancient Egyptian Coffin Texts
}

\author{
Prof. Sherif M. S. El-Sabban ${ }^{\text {a }}$
}

Mahmoud Hassan Ali ${ }^{b}$

a Professor of Egyptology, Tourist Guidance Department, Faculty of Tourism and Hotels, Minia University, Egypt b PhD Researcher, Tourist Guidance Department, Faculty of Tourism and Hotels, Minia University, Egypt

\section{Keywords}

\section{Andjety}

Busiris

Djedu

Coffin

Texts

Spell

\begin{abstract}
Andjety was the ancient Egyptian deity of the ninth Nome in lower Egypt, centered at Andjet, which was known as Busiris to the Greeks. He was also known by the names Anezti or Andjety and is considered one of the earliest Egyptian gods, possibly with roots in prehistoric times. Andjety is thought to have been a precursor of Osiris. Andjety he is depicted holding the crook and flail and has part of the Atef crown (the two feathers). King Sneferu of the Fourth Dynasty, builder of the first complete pyramid, is shown wearing the crown of Andjety. In the Pyramid texts the dead king is identified with Andjety. In the temple of Seti I at Abydos, the king is shown offering incense to Osiris-Andjety ${ }^{1}$ who is accompanied by Isis. He also is shown to have fertility aspects, being known by the epithet of "bull of vultures". His name is sometimes written with a stylized uterus in place of the feathers in the hieroglyphs.
\end{abstract}

\footnotetext{
${ }^{1}$ During the New Kingdom, occasionally even meet a compound god Osiris-Andjety, see DZA 21.889.150. From Seti I's temple at Abydos, the compound god Osiris-Andjety is a relatively late development: it's not attested before the New Kingdom, in most cases, a compound god is worshipped in the shape and form and appearance of the first/earlier - mentioned god, for example (Amun-Re looks like Amun, and Khnum-re looks like Khnum, so Osiris-Andjety looks like Andjety.
} 
This study will focuses on god Andjety, his forms, the main place of his worship and his role in general. This research studies this topic through the Coffin Texts spells that mentioned the name of God Andjety in several spells positions, also the writing those texts, translating and commenting on them, also the study will focus on studying the regalia scepters of god Andjety, signs and symbols which is related to God Andjety. trying to identify those regalia and symbols, and study it`s functions, history.

The main points that the researcher will study about this God, is Andjety`s body shapes, and the method and distribution of his symbols and insignia, also the study will focus on the two Ostrich back-to-back feathers which is the most s famous divine and insignia for god Andjety, whereas god Andjety was the first god appeared and wearied this two Ostrich back-to-back feathers crown, those two feathers crown and its relationship to royalty will be studied, and models of royal cartouches which contained the two feathers of Andjety and its symbolism also will be studied.

\section{Introduction}

There are many cities associated with the name of Osiris which causes some issues or arguments, In early texts Osiris was related to more than one site, the most important among these being Busiris ${ }^{2}$, a city in the delta whose Greek name 1 通 3 pr Wsir , means "House of Osiris ". Osiris is called "Lord of Busiris, and the epithet even precedes "Lord of Abydos" it has therefore been assumed that Osiris' original home was in the Delta, especially since the god of the Busirite region, mm was the only early symbol with a human shape to appear with feathers $(\check{s} w t j)$ Crook $(h k 3)\left\{_{6}\right.$, and flail ${ }^{7}(n h h){ } \bigwedge_{8}$, like Osiris. Therefore it was widely believed

2 Pierre Montet, Geographie de l'Egypte ancienne, 98.

${ }^{3} \mathrm{~Wb} 1,359.5 ; L G G$ II, $528 \mathrm{ff}$.

${ }^{4} \mathrm{~Wb} 1,207.12 ; L G G$ II, $175 \mathrm{f}$.

${ }^{5}$ James P. Allen, Middle Egyptian, 441.

${ }^{6}$ James P. Allen, Middle Egyptian, 442.

${ }^{7}$ It is a symbol of the ruler, the chief or the king and one of the symbols of authority. It was a bent staff and its origins get back the staff of shepherd in the beginning, the staff of shepherd was called awt (Wb. I , and appeared in the Sed-Festivals (Martin, 821), then it was developed into $h k 3$ staff which was taken by the king from Osiris. Originally it belonged to the god Andjety (Hassan, 1976) so it was the most of the time in the hands of the king, the god or in other words, it was held by the great men who had the prestige and authority. It might have been the aim of its bent that it was used to bring stray sheep at the beginning of its use by the shepherds and this staff is still used to lean on it when it is more length.

8 James P. Allen, Middle Egyptian, 442. 
that Osiris took these attributes from a deified Delta god-king Andjety mm с 549

\subsection{God Andjety}

The god Andjety is one of Egyptian's oldest deities, whose roots can be traced back even into the Predynastic Period. Although there is little information available on him, it can still reveal his characters.

\subsection{The god's portrait}

Few depictions of Andjety have survived. The majority of those are in the

Pyramid Texts (reproduced from Sethe's publication ${ }^{10}$ )
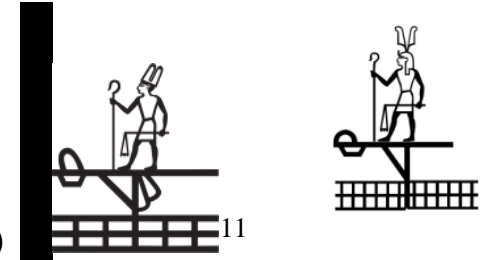

${ }^{12}(\mathrm{PT} 1833(\mathrm{~N}))$

He is shown as a standing male figure, with a crook in one hand and a flail in the other (some call it a fly whisk, or a whip). His undifferentiated body lends an air of archaism to the representation.

These attributes are immediately familiar as the crook and flail of Osiris, which were also regularly carried by the king. Yet there is a significant difference: Andjety's crook maintains its full original size, as opposed to the shortened form that was familiar from Tutankhamen's Coffins. On his head, the god has two feathers in a headband, of the same type as the feathers of the goddesses Maat and god Shu (ostrich feathers $^{13}$ ) that stand back-to-back

Perhaps can see here a premonition of the so-called Atef-crown 15 , later used by both the kings, and several gods - most frequently by Osiris.

A long strip or ribbon hangs from the headband behind the god. (The headband itself is not recognizable in this tiny drawing, but other depictions later would be outlined

\footnotetext{
${ }^{9}$ LGG III, 799

${ }^{10}$ Sethe, Kurt. Die Altaegyptischen Pyramidentexte nach den Papierabdrücke $n$ und Photographien des Berliner Museums. Leipzig: J. C. Hinrichs'sche Buchhandlung, 195.

${ }^{11}$ This sign according to JSesh program the form of god Andjety not correct, because of the two feathers not belongs to him, its belongs to god Amun, the Two Feathers of Andjety always appears stands back to back . 12 The researcher draws the exact shape and form of God Andjety According to the Coffin Texts.

${ }^{13} \mathrm{LA}, \mathrm{II}, 142-145$.

${ }^{14}$ The researcher draws the design of the Two Ostrich feathers (back-to-back) According to the forms and appearances of God Andjety in the Coffin Texts.

${ }^{15}$ Atf "Atef-Krone (Krone der Götter)" (Wb 1, 23.2-3) (lemma-no. 326)
} 
Such tall feathers are also worn by Amun, though again there is a difference: Min and Amun wear "straight" plumes $\lfloor .16$

Egyptologists have generally paid more attention to the crook and flail, than to the feathers $\boldsymbol{S}$. However a determinative for ${ }^{`} n \underline{d} . t j$ in the Pyramid texts from the Teti pyramid could be an indication that for the ancient Egyptians, the feathers mattered more. The traditional determinatives for "a god in general': the falcon on a standard ${ }^{17}$

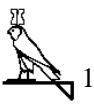

${ }^{8}$ (PT 614 T). To emphasize that in this case, Andjety is meant, and not just any god, the falcon is crowned with Andjety's two feathers. It seems then, that for the Egyptians these feathers were the distinguishing characteristic of the god.

The archaeological evidence, which has reached us until now, indicates that the most ancient associations between the scepter of royalty and the deities were the god Andjety. He was one of the first deities associated with the staff and represented holding it in his hand from the earliest times ${ }^{19}$. In those days the bearer of the staff was a tribal chief or the king himself, and in that period the gods also carried the Scepter of royalty ${ }^{20}$.

\section{God Andjety in the ancient Egyptian Coffin Texts:}

The Coffin Texts also mention Andjety several times. Because the Coffin Texts are written in either cursive hieroglyphs or an early type of hieratic, some of the finer distinctions of certain signs get lost, so should always refer back to the more detailed signs from the Pyramid Texts to get the god's exact features, such as the type of staff and scepter in his hands (crook and flail) and the number and type of feathers on his head.

\footnotetext{
${ }^{16}$ Wb 4, 425.10-11; LGG VII, 169 ff)

17 The living king of Egypt was identified as an earthly Horus, and from the late Predynastic Period (c. $3100 \mathrm{BCE}$ ), the king bore a special royal "Horus name." The falcon, as the sacred animal of Horus, came to symbolize divine kingship, as the king was the earthly representation of Horus, see discussion of the falcon in Egyptian art and Egypt in P. F. Houlihan, The Birds of Ancient Egypt, The Natural History of Egypt 1 (Warminster, 1986) 46-48. See also R. Bailleul-LeSuer, ed., Between Heaven and Earth: Birds in Ancient Egypt, exh. cat., Oriental Institute of the University of Chicago (Chicago, 2012) 178-88, which includes discussion of modern scientific analysis of mummified bird remains from Egypt.

${ }^{18} \mathrm{~Wb}$ 1, 107.12-19; Wilson, Ptol. Lexikon, 98 f.

${ }^{19}$ Otto, "Anediti"., LÄ. I.269- 270.

${ }^{20}$ Hassan, Ali, Stöcke und Stäbe im Pharaonischen Ägypten, MÄS, 170.
} 
In three spells, the word end.tj the god Andjety is only mentioned in one spell, Will start with references to a location.

\subsection{CT Spell 60}

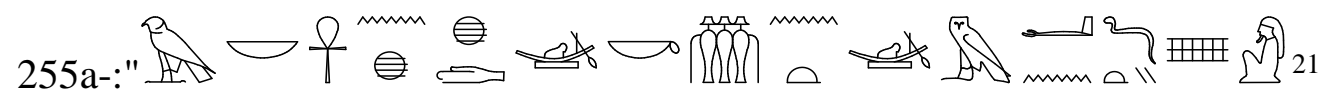

$H r n b^{\top} n h \underline{h} h d(w)=k \operatorname{hnt}(w)=k m{ }^{\top} n \underline{d} . t j$

O Horus, Lord of Life, fare downstream and upstream from the Nome of Andjety

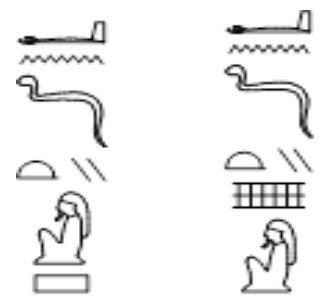

These two ways of writing using phonetic signs as well - are very useful because they confirm that can actually interpret the other writings to really mean Andjety too. These writings simply consist of the sign of the "Human form" supplemented with one or more signs indicating a location:㒷 or .

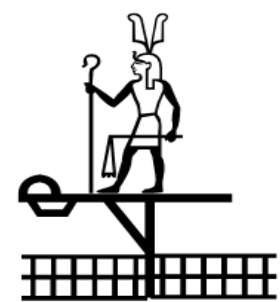

In all other writings of Andjety in the Coffin Texts, we only find the "Human form" with the location determinatives.

\subsection{CT Spell 337}

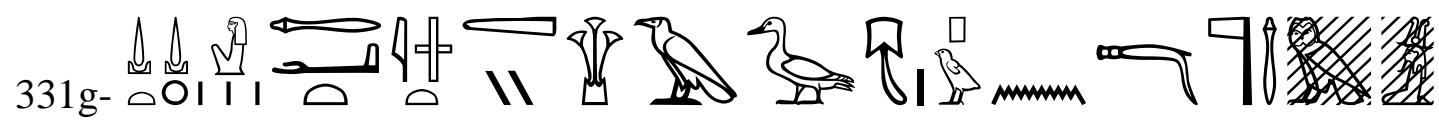

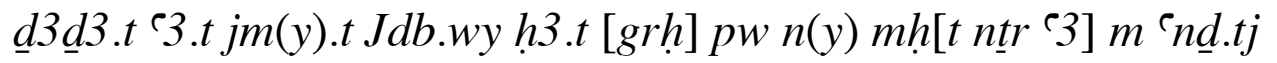

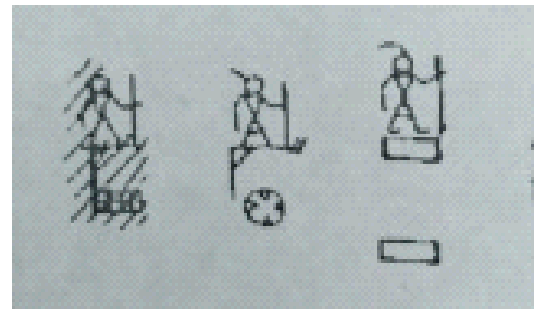

The great tribunal which is in the Two Banks of the Kite (?) on that night of the drowning of the great god $^{22}$ in Andjety the great god must be Osiris, who according to one part of the myth was drowned. Again, from the context it is clear that are dealing with a location. These are the variant writings, as De Buck gives them (in IV-331g). All the three texts are conveying the sense of a location, and all three can be rendered as "Andjety's Nome".

\footnotetext{
${ }^{21}$ lists make it clear, that this is writing for the name of a -countless parallels from Nome $s p 3 t / 5 p 3 t$ The sign Nome. In fact, later Nome -lists consistently show this sign as the name of the 9th Nome of Lower Egypt ${ }^{22}$ The (great god) is Osiris see the original text, De Buck, Coffin Texts, IV-331g
} 


\subsection{CT Spell 629}

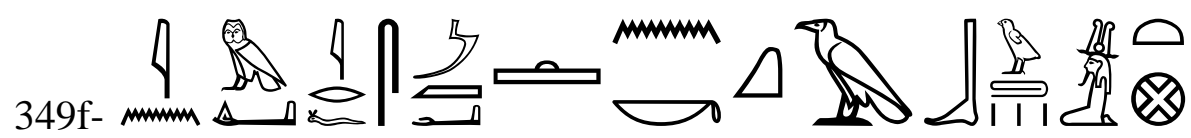

$j n-m(j) j r f \operatorname{sm} 3^{\ulcorner} n=k q 3 b . w\ulcorner n \underline{d}-t j$

Who is he who will put the windings of Andjety?

A bit further on in the same spell (Spell 629) the expression "winding of Andjety" returns three more times ${ }^{23}$, in total, three are - variants included - six writings. Five of these have an ending in .t, which strongly suggest a reading of Andjet not Andjety

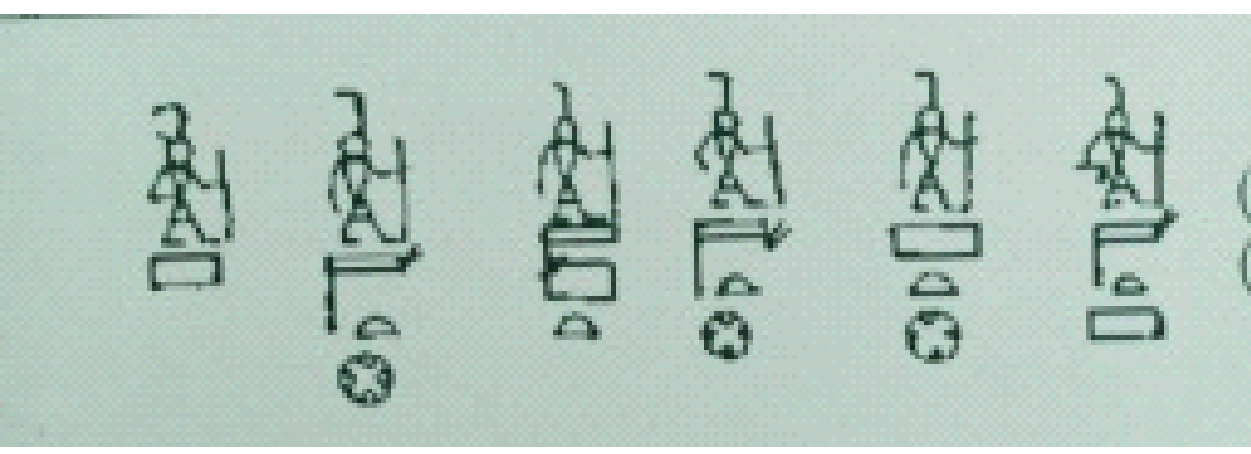

\subsection{CT Spell 468}

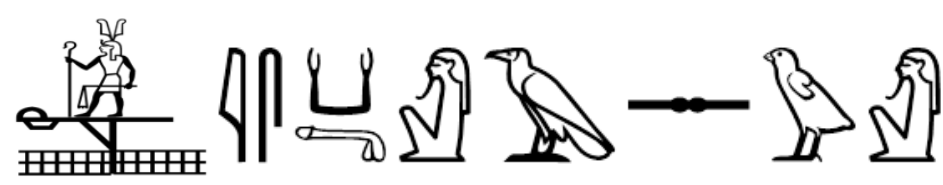

${ }^{\top} n \underline{d}=t j$ js $K 33$ s.w

(And) following the example of Andjety the Bull of Vultures.

In CT V-385o- the only line where Andjety is referred to as a god:

The CT V-385o says: "I immerse the waterways as Osiris, Lord of corruption, as Andjety, Bull of vultures".

The latter expression does give some hope of seeing yet another glimpse of Andjety revealed, but alas: it's a most dark expression. From the translation, might expect it to refer to a relationship with certain goddesses that appear in the form of

\footnotetext{
${ }^{23}$ On pages VI-249 and VI-250. Faulkner translates: " the windings of Andjet', and adds as comment to the word "windings": '...presumably of the Andjetian waterways'.

${ }^{24}$ See De Buck, Coffin Texts, VI-248h (2x), I-249F (2X), vi-249k and VI-250v.)
} 
vultures, such as Nekhbet ${ }^{25}$ or $\mathrm{Mut}^{26}$, but this is the actual writing:

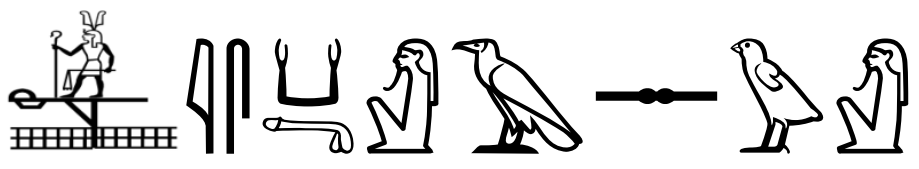

The vulture in this case is $(\mathrm{G} 1)$ instead of names of Nekhbet and Mut are written. In any case, the reference to a bull is much more likely to pertain to Osiris in this case, for Osiris is regularly portrayed as one with unusual sexual powers. ${ }^{27}$

An interesting element in this phrase is that it uses crossed-over elements:

I immerse the waterways as Osiris, Lord of corruption, as Andjety, Bull of vultures.

\begin{tabular}{|c|c|}
\hline Waterways & \\
\hline Bull of vultures & Andjety \\
\hline
\end{tabular}

Perhaps it was not intentional, but the waterways could refer to Andjety, whereas the Bull of vultures could point to Osiris. If it's intentional, it's a poetic way of equating one with the other.

The writing of Andjety's name in this CT spell is very common,

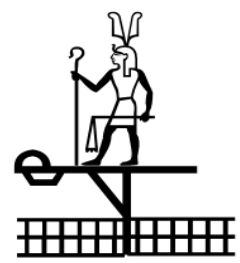

\subsection{A deified local chief}

The god Andjety is often described as a deified local chief from the Predynastic period.

According to Eberhart Otto ${ }^{28}$, the idea that in the figure of Andjety, might actually be looking at the "picture" of a Predynastic ruler (no matter how dim or stylized), is immensely attractive. But alas, even the most attractive idea cannot reliable evidence for this position; the following elements are usually enumerated:

Andjety is called "headman of his Nome" or "who presides over the eastern

\footnotetext{
${ }^{25}$ Egyptian goddess, the vulture goddess of el-Kab (Nekheb) and the titulary goddess of Upper Egypt. Shown either as a vulture hovering over the king or as a woman wearing the White Crown of Upper Egypt. The Greeks identified her with Eileithya.

${ }^{26}$ Mut was a daughter of the sun god like Sekhmet, Hathor, Bastet, Nekhbet and others -- goddesses known as the "Eye of Re." They were both benign and dangerous and could appear as gentle cats or fierce lionesses. Because they influenced the Nile floods and could both cause and cure disease, their cults were vital to Egypt.

27 And not without reason: to beget a son after death is quite an feat.

${ }^{28}$ Otto, Lexikon (I, 269-270).
} 
Nome's", in historic times these are typical provincial titles.

Two of his attributes are the crook and flail: generally believed to have been ancient emblems of dominion.

He is always portrayed as a man. Taken together with the epithets and emblems, this adds up to the portrait of a ruler.

The observations are all correct, but none points in the right direction.

Both crook and flail are symbols of dominion, but so are crowns. Crowns are regularly worn by several gods, Atum with a double Crown, or Neith with the Red Crown. The fact that these are symbols from the realm of human rulership, used by gods, cannot be taken as indication that the gods in question originally were human rulers. Like the epithets, they just stress the god's power ${ }^{29}$.

The flail is in regular use by other gods, too: especially when they are depicted as birds ${ }^{30}$ but also by Min, and Amun when he assumes the guise of Min $^{31}$. None of these make plausible Predynastic rulers.

Andjety like other gods was commonly depicted in a human figure. God Atum the perfect example of ancient Egyptian gods who commonly depicted in a human figure.

So Andjety may have been, rather than a deified local ruler, the main god of a political unit that existed in the eastern Delta, sometime during the pre- or Early Dynastic Period.

Perceived as the force behind the successes of the region, he received the honorary titles of "headman of his nomes", and "foremost of the Eastern Nomes" like the god Geb could be called "lord of the Two Lands". And just like Atum later received the double Crown, he was equipped with feathers, crook and flail - trappings that may have been typical for a ruler from the Delta region.

\section{The regalia scepters of god Andjety:}

\subsection{The šwty $\sqrt{\text { crown }}$}

The šwty crown, as worn by some kings, had links with the gods Andjety. Since the šwty crown represented kingship in the real world ${ }^{32}$, it may have been a crown of the living king and its use in statues of royal ancestors may highlight the blurred lines between the living king and his ancestors, especially when statues were created in the reign of a king and then used for many years afterwards ${ }^{33}$.

The distinction made between living and deceased Kings is debatable, and it is

\footnotetext{
29 Willockx, S, Magic and Religion in Ancient Egypt,29.

${ }^{30}$ See e.g. Mut, as a vulture: Gr. G15.

${ }^{31}$ Willockx, S, Magic and Religion in Ancient Egypt,29.

${ }^{32}$ Collier, S., the Crowns of Pharaoh: their Development and Significance in Ancient Egyptian Kingship. 60.

${ }^{33}$ Collier, S., the Crowns of Pharaoh: their Development and Significance in Ancient Egyptian Kingship. 58.
} 
possible that state sponsored images, such as cult statues, encouraged this blurring of lines ${ }^{34}$. This, in turn, added to the concept that the living king was one of a line of 'eternal kings'.

4.2. The Crook $(h k 3) ?_{35}$

Knowing the original function of the crook used as a symbol representing the roles of the king, the crook was known as the ( $h k 3)$ in Egyptian. It originated from the staff that shepherds used to protect their sheep. The crook represented the king role as a shepherd in caring for the people of Egypt.

The crook could yet pass over into the royal regalia, until such time $5^{\text {th }}$ dynasty, the crook by itself is not in use as an honorary symbol: neither with gods, nor king.

\subsection{Flail $(n h h)$}

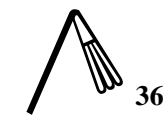

The flail ${ }^{37}$ was known as the $(n h h)$ or $(n h 3 h 3)$

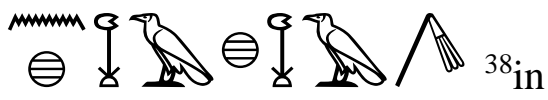
Egyptian. It was a rod with three strands of beads attached to the top. Although historians cannot agree exactly what this was used for, there are two primary interpretations of its origin.

The first is that it was a weapon used to defend a flock of sheep. In this interpretation, the flail represented the king's responsibility to establish the order (through punishment, if necessary) that was essential to sustaining society.

The second interpretation is that the flail was used as an agricultural tool to thresh grain. In this interpretation, the flail represented the king's role in providing for the people of Egypt and protecting land that could grow food for the people. Together, the crook and flail were used to represent the two most important roles of the king.

\section{The Divine Royal Cartouche:}

\subsection{The two Ostrich feathers cartouche}

The cartouche is an elongated form of the Egyptian shen ${ }^{39}$-hieroglyph that encloses and protects a royal name or, in specific contexts, the name of a divinity.

\footnotetext{
${ }^{34}$ Redford, D., Pharaonic King-Lists, Annals, and Day-Books: a Contribution to the Study of the Egyptian Sense of History. (SSEA Publication 4.) Mississauga, 54-55.

${ }^{35}$ Wb 3, 170.23-173.2; vgl. Jones, Titles $O K$, no. 2426

${ }^{36}$ Wb 2, 306.11-14; FCD 137; Wilson, Ptol. Lexikon, $538 \mathrm{f}$.

${ }^{37}$ The flail is already in evidence on the Narmer Palette, right at the beginning of the 1st dynasty.

${ }^{38}$ Faulkner, R.O., A concise dictionary of middle Egyptian, 137.

${ }^{39}$ The cartouche derives from the Egyptian shen-ring, a hieroglyphic sign depicting a coil of rope tied at one end, meaning ring, circle," the root $\breve{s}$ ) shen) expressing the idea of encircling .Symbolically, the cartouche represents
} 
A king's throne name and birth name were each enclosed in a cartouche, forming a kind of heraldic motif expressing the ruler's dual nature as both human and divine. The cartouche could occur as a simple decorative component. When shown independently the cartouche took on an iconic significance and replaced the king's, or more rarely, the queen's, anthropomorphic image, enabling him or her to be venerated as a divine entity.

Conversely, the enclosure of a god's or goddess's name in a cartouche served to render the deity more accessible to the human sphere.

During the early $18^{\text {th }}$ Dynasty the two ostrich feathers shown back to back were placed above the king's cartouche on certain cult statues or reliefs that seem to relate to the deification of the monarch. These date from the reign of Hatshepsut onward and were used more frequently during the Ramesside period. These feathers placed back to back refer back to the earliest known symbolism of Andjety and give greater credibility to the notion that he was most likely a leader or king who was then deified, either in his own lifetime or later. No other deity had this symbolism. On the Atef crown, very often worn by Osiris, they flank the sides of a tall white crown along with other symbols, and this too reinforces Andjety's connection with both Osiris and kingship.

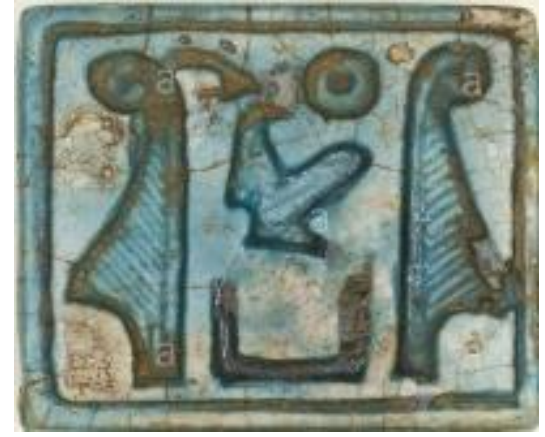

Plaque: Cartouche of queen Hatshepsut Maatkare Flanked by Two Feathers. ${ }^{41}$

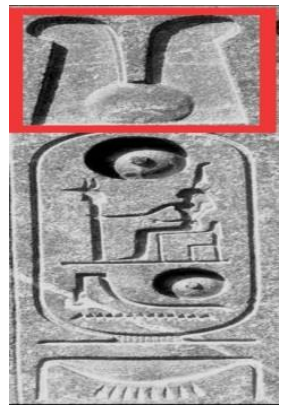

Cartouche of king Ramesses II Usermaat-re Setep-en re crowned by Two

Feathers. ${ }^{40}$

the encircling of the created world by the sun disc - that is, the containment of "all that the sun encircles." Originally, the shen-ring was

Probably an amulet formed from a length of papyrus rope looped into a circle with an additional binding. The cartouche is an elongated shen-ring, extended to accommodate and magically protect a royal name, see , Barta, Winfried, Der Königsring als Symbol zyklischer Wiederkehr. Zeitschrift für Ägyptische Sprache und Altertumskunde 98, pp. 5 - 16.

${ }^{40}$ Details from the front side of the throne of king Ramesses II statue - first pylon - Luxor temple.

${ }^{41}$ After, the Art Institute of Chicago Museums. 


\section{Conclusion}

In conclusion, this study can clear up many points, as the following:

Andjety was first linked with the Delta and was later linked with the $9^{\text {th }}$ Nome of Lower Egypt as a whole. His place of origin was in the $9^{\text {th }}$ Nome of Lower Egypt (Busiris), where he came into being as the god of a waterway, and was named after Andjety, making him the first example of a god with his roots so deep in a location that can call him a "territorial god" or a "local god".

Andjety is more of a descriptive label, or even an epithet, than a name, it merely points out a connection between the god and a location. The cult of Andjety is earlier than the cult of Osiris; the crook and flail which always appear held by Osiris, originally belonged to Andjety, so Osiris inherited them from him.

Andjety's nature is unknown; there is no evidence of his Cult chapel, and he is never depicted shrouded. Andjety was at some point the most important god of the region and in that regard he was portrayed as a local ruler, decked out with the associated regalia (crook and flail and headband with ribbon and two feathers.).

The surviving texts give us only the name of Andjety and there is no mention of any of his activities other than being the first god to appear holding a crook and flail. The divine kings and rulers hold the same crook and flail as god Andjety.

The two feathers on the sides of the Atef crown belong to the god Andjety. The two feathers inside or on the top of the cartouche for the divine kings also refer back to the god Andjety. Andjety's emblems of rulership may possibly have been borrowed from those of a Predynastic Lower Egyptian ruler. 


\section{Bibliography}

Allen, J. P., J. Assmann, A. B. Lloyd, R. K. Ritner and D. P. Silverman, Religion and Philosophy in Ancient Egypt, YES 3, New Haven, 1989.

Adolf Erman, Hermann Grapow (ed.): Wörterbuch der Aegyptischen Sprache. AkademieVerlag, Berlin 1926-1961.

Barta, Winfried Der Königsring als Symbol zyklischer Wiederkehr. Zeitschrift für Ägyptische Sprache undAltertumskunde 98, pp. 5 - 16.

Pierre MONTET - Géographie de l'Egypte Ancienne, 2 Volumes, Paris, 1957 -

Claude Carrier, Textes Des Sarcophages: du moyen empire egyptien, 3 vols,Paris, 2004.

Faulkner, R. O., A Concise Dictionary of Middle Egyptian, Oxford, 1962. The Ancient Egyptian Coffin Texts, 3 vols, Warminster, 1973-78.

James P. Allen, Middle Egyptian: An introduction to the language and Culture of Hieroglyphs, Cambridge, UK, 2000.

Leitz, C. (ed.), Lexikon der ägyptischen Götter und Götterbezeichnungen, 8 vols, OLA 110116 and 129, Leuven, 2002-2003.

Helck, Wolfgang and Otto, Eberhard, Lexikon der Ägyptologie, 7 vols.

Wiesbaden, 1975-1992.

Donald B. Redford ,Pharaonic King-Lists, Annals and Day-Books: A Contribution to the Study of the Egyptian Sense of History) SSEA Publication ,(Paperback - February 1, 1986

Karl W. Butzer, Early Hydraulic Civilization in Egypt: A Study in Cultural Ecology (Prehistoric Archaeology and Ecology) Paperback, University of Chicago Press; Reprint Edition (August 1, 1976)

Hermsen, E., Die Zwei Wege des Jenseits: das altägyptische Zweiwegebuch und seine Topographie, OBO 126, Freiburg and Göttingen, 1991.

Hoffmeier, J. K., 'Are There Regionally-Based Theological Differences in the Coffin Texts?', in: Willems (ed.), The World of the Coffin Texts, 45-54.

Hornung, E., Altägyptische Höllenvorstellungen, ASAW 59/3, Berlin, 1968.

Richard H. Wilkinson,Reading Egyptian Art: A Hieroglyphic Guide to Ancient Egyptian Painting and Sculpture, Thames and Hudson, 1992.

Robinson, P., 'as for them who know them, they shall find their paths: Speculations on the Ritual Landscapes in the Book of the Two Ways', in: Mysterious Lands, 139159.

Willockx, S. 2007. Magic and Religion in Ancient Egypt: Amentet, Andjeti and Anubis. Zeeland, NL: self editor. 